\title{
Mactare. Etymology and Anthropology of the Archaic Sacred
}

\author{
Claudio Tugnoli \\ Department of Sociology, University of Trento, Trento, Italy \\ Email: tugnoli53@virgilio.it
}

Received 30 May 2015; accepted 7 August 2015; published 11 August 2015

Copyright (C) 2015 by author and Scientific Research Publishing Inc.

This work is licensed under the Creative Commons Attribution International License (CC BY). http://creativecommons.org/licenses/by/4.0/

(c) (i) Open Access

\begin{abstract}
In this article I will show that the victimary theory of René Girard can make a decisive contribution to the interpretation and solution of etymological and semantic questions of the verb "mactare", which is basic in the terminology related to the topic of the sacrifice. The victimary anthropology provides the hermeneutical key that allows us to consider the expressions "mactare Deum" and "mactare victimam" as genetically synonymous. The theory of René Girard seems to perfectly explain the coexistence, in "mactare victimam", of two meanings: kill on the one hand, raise and glorify on the other hand. In the case of original lynching, which is mostly hidden in the myth, the victim, which at first is killed for it is believed that the cause of all evils is deified by the persecutors as the cause of all goods. Hence the need to strengthen and renew periodically, through animals or human sacrifices, the saving power of divinity established with the murder of the first victim. That's why killing and glorifying coexist in "mactare", which is both "mactare victimam" and "mactare Deum", since the verb means to kill when referring to a victim and to glorify when referring to God. Indeed, the deification of the victim is the result of his killing.
\end{abstract}

\section{Keywords}

Etymology of "Mactare", Sacrifice, Victimary Anthropology, Scapegoat theory, Sacralisation of the Victim, Enantiosemia, Archaich Sacred

\section{Foreword}

With this brief paper, I intend to demonstrate that the scapegoat theory of René Girard can provide a significant contribution to the interpretation and solution of vexatae quaestiones of an etymological and semantic nature regarding the verb mactare that holds a central place in the terminology relating to the sacrifice theme. Victimary anthropology provides the ermeneutic key to the consideration that the expressions mactare deum and mactare victimam are genetically synonymous. 


\section{Etymology and Semantics of Mactare}

The Georges-Calonghi dictionary gives the following meanings for mactare: to glorify, to honour, to praise (aliquem honoribus mactare); to honour a divinity with a sacrifice, to appease (puerorum extis deos manes mactare, Cic.). Mactare also refers to animal sacrifices; it also means to immolate, to sacrifice, to consecrate (hostium legiones Telluri ac dis manibus mactare, Liv.; perfidos et ruptores pacis ultioni et gloriae mactare, Tac.). In a more general sense, mactare means to kill, to put to death, to punish, to ruin, as for example internal and external enemies. Mactare is a denominative verb derived from mactus, a term the ancients derived from magis auctus, although Georges-Calonghi considers this etymology implausible (Calonghi, 1967). Mactare is present in the Italian word "mattanza", which according to Giacomo Devoto came to the Italian language from the Spanish matanza (killing), in turn derived from the verb matar, to kill, that is clearly derived from mactare (Devoto, 1966: p. 261). A more updated and synthetic treatise about the etymology of mactus and of mactare is found in the Lateinisches Etymologisches Wörterbuch that justifies the double construction of mactare (aliquem aliquā rēe, alicuī aliquid) via the parallelism with dōnō, circumdō, etc. (Walde, 1982: pp. 4-5). The specification leads to the observation that the double construction assumes two opposite ways of conceiving the triadic relationship among he who gives, he who receives and what is given. With the first construction (aliquem aliquā rē), the thing that is given is a mere tool at the service of the operation regarding the recipient; with the second construction (alicui aliquid), the thing that is given has value per se. In the first case, the primary goal is to enhance the value of or to glorify the recipient, while in the second case the object passing from one to the other takes front stage. A widely acclaimed dictionary (Conte, 2000: p. 714) provides four main meanings of mactare, following the (by now) canonical order: 1) to honour, to celebrate (eos mactant honoribus: Cic. Rep. 1, 67); 2) to sacrifice, to immolate (with the dative of the divinity to whom one sacrifices, e.g.: mactavit taurum Neptuno: Verg. Aen. 3, 118); 3) to kill (damnos mactabis et apros: Mart. 1, 49, 24); 4) to afflict, to torment, to punish (with the instrumental ablative: Nonne hunc summo supplicio mactare imperabis? Cic. Cat. 1, 27). Starting from the last meaning, it is possible to reconstruct the main stages of the constitution of the archaic sacred according to the scapegoat theory (Girard, 1980, 1983, 1987): a victim, accused of being the cause of the violence and of the undifferentiating chaos spreading through the community, is killed and sacralised. The lynching of the victim completely transforms its evil omnipotence into beneficial omnipotence because its expulsion restores peace and order. The redeeming power of the divinity shall be renewed periodically by means of sacrifices made in its honour, consisting in the ritualistic immolation of a human or animal victim. The reconstruction of the phases in which the sacred archaic is constituted shows how the canonical order of the meanings of the term mactare reverses the genetic sequence identified by the scapegoat theory in which the celebration of the divinity by means of a sacrifice is the final phase of the entire process: one starts from the identification of the victim who, unanimously considered responsible for the dissolution of the community, is thus predestined to ruin in order to save them all.

The Lexicon totius latinitatis offers a more analytical picture of the semantics of mactare by distinguishing between a proper meaning and a derived one, both in re profana and in re sacra. Mactare would seem to derive from an uncommon mago, magere, derived from the root word mag that we also find in magis and magnus. In re profana, mactare properly means augere, while in a derived sense it is used to ironically indicate a tragic event resulting in damage, as when in Italian one says that someone has been "visited by misfortune". In re sacra, properly speaking, mactare has the main meaning of "deos vel deorum felicitatem augere, atque adeo deos honorare, honorem diis adhibere"; secondly, it means to solemnise, to celebrate. Figuratively, it mainly means "to offer in sacrifice to the gods"1. Therefore, the main objective of mactare is the god that one wishes to make more powerful and happier, and secondly it means to immolate a victim to the gods, to make a sacrifice to the divinity in order to honour it. We shall see how, starting from the identification of the victim to be offered in sacrifice, an intimate link can arise between the proper meaning and the figurative meaning of mactare. The divinity to which one makes a sacrifice, from a mythical viewpoint, owes its own genesis to the founding killing of a victim that is then sacralised.

The Novus Linguae Latinae Thesaurus highlights interficere as the meaning of mactare and to immolate. Second place is taken by the meaning to honour, to elevate, to augment; in third place, for mactare it gives to be

${ }^{1}$ Lexicon totius latinitatis ab Aegidio Forcellini seminarii patavini alumno lucubratum deinde a Iosepho Furlanetto eiusdem seminarii alumno emendatum et auctum, nunc vero curantibus Francisco Corradini et Iosepho Perin seminarii patavini item alumnis emendatius et auctius melioremque in formam redactum, Tom. III, curante Iosepho Perin cum appendice eiusdem, MCMLXV Arnaldus Forni excudebat Bononiae Gregoriana edente Patavii, p. 142. 
hit or afflicted by misfortune or damage. As regards mactus, it states: "Origine sua videtur participium verbi obsoleti Magere, quod idem significasse putamus, quod augere, quodque se habeat ad adverbium Magis ita, ut Graecum mogan ad mogis. Certe ex eodem fonte sunt magis, maginus contracte magnus maior quasi magior, maximus pro magissimus: tum ut ex Ago agito, ita ex Mago Magito contracte Macto: ex eodem Mago est Magitus Mactus, ut pro agitus actus, pro augitus auctus etc.” (Gesner, 1749: III, p. 168). If the Lexicon totius latinitatis considers as proper and primary the expression mactare deum, the Novus Linguae Latinae Thesaurus attributes the proper meaning to mactare victimam. The Dictionnaire étymologique de la langue latine by Ernout and Meillet (1967: p. 376) underlined that mactus, macte were used in the formula that officiated the sacrifice: mactus sies, esto or macte esto ${ }^{2}$. It adds that the denominative verb mactare is connected to mactus in the two meanings of 1) to honour the gods, and 2) to immolate a victim, to sacrifice, to kill. In disagreement with the theory that attributes the two meanings to two different verbs (to honour from mactus and to immolate from a root that seems to correspond to the gothic mekeis and $m \bar{a} k i$ ("sword"), Ernout and Meillet observe that most likely the meaning of "to immolate" comes secondarily from the meaning "to honour the gods". In other words, the distance from "to honour with sacrifice" to "to offer a sacrifice" is easy and short (Ernout \& Meillet, 1967: p. 376). The observation is pertinent, as will be seen further on, and not only in etymological terms. The verb mactare has three main semantic levels: to kill, to immolate a victim, to honour the gods. And yet it is still unclear why to immolate, to sacrifice a victim must have the function of honouring the gods and of propitiating the god's redeeming intervention in favour of the sacrifiers.

The three semantic levels of to kill, to immolate a victim, to honour the gods are taken up by the Thesaurus Linguae Latinae (1966), but significantly in reverse order (Thesaurus Linguae Latinae, 1966: p. 21). The implication is that, given the derivation of mactare from mactus, macte (that appear in propitiatory formulas lacking any reference to the killing of a victim), mactare too may have as main and characteristic meaning that of to amplify, to honour, to elevate. The Thesaurus proposes a sophisticated subdivision of the various acceptations in which the three main meanings are found. Mactare in the sense of auctare, ampliare may be intended both in a positive way (bonis rebus: praecipue honoribus), as referred to men, to the gods, to animals, to things ${ }^{3}$, and in a negative way, in expressions in which, for example, one hopes for or one promises someone a ruinous outcome ${ }^{4}$. Noteworthy is this declination of mactare in the sense of ampliare (to amplify), with two opposite acceptations, such as benedire (to bless) and maledire (to curse); to let live and prosper on the one hand and to damage and kill on the other. After all, the action of demolishing implies the awareness of the importance and value of what is about to be destroyed. Vice versa, when one elevates someone or something, one attributes to that someone or something a superior value in order to send them away, to render them harmless, to expel them from the community. Isn't it true that sometimes one takes revenge on someone by exaggeratingly praising them? Mactare has a second meaning, sacrificare, immolare (alicui) aliquid, that the Thesaurus divides into two meanings: a proper one (with reference to the immolation of human or animal victims) and a figurative one (for example: one can sacrifice one's own will by following to the letter the will of another person). Thirdly, mactare means interficere both properly and figuratively. In the proper sense, men and animals can be killed but so they are victims and therefore are immolated (Thesaurus Linguae Latinae, 1966: pp. 22-23). This link allows us to connect the third meaning of mactare to the second. The circle comes round when we add that one can kill someone only by virtue of the importance and value we attribute them. Thus, somehow we must honour, elevate someone before knocking them down for their destruction to make sense. The same with blasphemy, where the heartfelt cursing of God assumes a convinced but implicit attribution of omnipotence to that God. One doesn't kill someone to get rid of them if not by starting from a preliminary super-evaluation of the power they have to cause great damage (or something perceived as such) to he who decides to destroy them. Men and things that are not assigned any value cannot be devalued. We can deny only what we have said. Indeed, the action of negation is implicitly an action of affirmation that at the same time is denied-like when we remove an obstacle that impedes us from proceeding along the way: we recognise the importance of the obstacle only to the extent to which we feel the need to remove it, and vice versa.

Certainly more complex is the voice of Emile Benveniste (1976) dedicated to sacrifice in his Vocabulaire des institutions indo-européennes. The verb mactare in classical times, writes Benveniste (1976), meant "to sacrifice

\footnotetext{
${ }^{2}$ In Cat., Agr. 134, 2, 3, for example: Juppiter te...bonas preces precor uti sies volens propitius mihi liberisque meis domo familaeque meae mactus hoc ferto ....Iane pater...macte uino inferio esto.

${ }^{3}$ Arnob. Nat.: animas inmortalitatis condicione mactatas (Thesaurus Linguae Latinae, 1966: p. 21).

${ }^{4}$ Enn., for example: Qui illum di deaeque magno mactassint malo! (Thesaurus Linguae Latinae, 1966: p. 21).
} 
an animal”. Since mactus is used in the form macte! meaning “come on!”, therefore with a meaning that is quite different from mactare, one thinks that the Latins had two verbs mactare, one with the meaning "to kill" and the other "to exalt, elevate, fortify". Benveniste (1976) rejects this theory, however. There is only one verb mactare. Although he finds the etymology of mactus proposed by the ancients (i.e. from magis auctus) seriously implausible, Benveniste (1976) deems the notion transmitted by mactus in the Latin texts, "that of growth, of reinforcement of the god, obtained by means of the sacrifice that nourishes it" as fully legitimate (Benveniste, 1976: p. 453). Benveniste (1976) sees in mactus a verbal adjective *mag-to parallel to *mag-no, evoking two forms of verbal adjective: that in—no indicates the natural status, the permanent inclination of something; that in — to indicates the status or condition to which one is transferred. The denominative verb mactare therefore indicates the operation via which something is made great, bringing it to the status of mactus. Thus we can understand the use of the expression mactare deum extis, understood as to honour, to glorify the divinity by means of sacrifice. Via the sacrifice, the divinity is made greater and stronger. Mactare also appears in the expression mactare victimam, however, which means "to offer a victim in sacrifice", developing also the meaning of putting to death, of killing, preserved in the Spanish term matar. Benveniste (1976), however, does not explain the relationship between the two main meanings of mactare-to make greater, to strengthen, to honour, to glorify and to sacrifice, to kill, to immolate-despite the significant semantic opposition between the two acceptations. Words usually don't have one meaning and at the same time the reverse meaning too (example: life and death; joy and pain; war and peace). Speakers do not use the same word to designate opposite qualities or states. Or at least, this is the rule that logical semantics implies should be followed by any language's lexicon. Unless this is a special case of enantiosemia, and indeed many languages have terms with opposite meanings. A pioneer in this direction was the glottologist Karl Abel, who first focused on the enantiosemia phenomenon (Basile, 1999; Peduto, 1993).

\section{Double Meaning of Primal Words?}

Freud (1974) confesses he came to understand that dreams process the contents of waking life while doing away with negation, so that in a dream anything can mean its contrary, only thanks to his reading of the essay by the glottologist Karl Abel Über den Gegensinn der Urworte, published in Leipzig in 1884 (Freud,1974: pp. 185-186). Freud (1974) declared he was surprised to discover that the oneiric process occurs based on a method that illustrates a property of ancient languages, in which it is possible to find a large number of terms that have two opposite meanings. With special focus on the language of ancient Egypt, Abel pinpointed another surprising fact: the existence of compound words in which two vocables of antithetical meaning are united so as to form one single word which, however, bears the meaning of only one of its two constituents. Abel believes that these compound words were created not with the intention of creating a third concept but rather to express the meaning of one of the two terms, a part that would have had the same meaning by itself, explaining the phenomenon on the basis of the creation of concepts by comparison. All determinations of reality are relative, such as inside-outside, near-far, young-old, light-darkness, etc. If it were always light, we should not be able to distinguish light from dark, day from night. Nothing on earth is independent, and interdependence finds its most eloquent expression in relative terms, such as right-left, before-after, up-down, etc. If at the ontological level hot does not exist without cold, at the logical level we are unable to think of heat without coldness. "Man", Freud (1974) writes in quoting Abel, was not in fact able to acquire his oldest and simplest concepts except in opposition to their contraries, and only learnt by degrees to separate the two sides of the antithesis and to think of one without consciously comparing it with the other” (Freud, 1974: p. 188). According to Abel, primitive man was able to communicate to others which of the two sides of the double concept he was referring to by using explicative images in writing and by gesturing when speaking. The most ancient roots hold the double antithetical meaning. As the language evolved, the ambiguous words split into two terms, obtained by means of the phonetic modification of the same root. By way of example, Abel mentions the word ken-"strong-weak"-in Egyptian hieroglyphics, that divides into ken "strong” and kan "weak" (Freud, 1974: p.188).

In the historical development of the language there is the tendency to communicate every concept using a single, autonomous term having its own independent phonetic capacity. The phenomenon of the phonetic-lexical separation of each concept may be interpreted both as progress, in that it facilitates the comprehension of the lexicon via the institution of the semantic unequivocalness, and as regression, since the cognitive action accompanying the production of the message loses the comprehension of the interdependence between the things of the world and thus between the corresponding concepts. That a term means only one thing appears to be an im- 
poverishment when compared to the phase in which words expressed a double meaning. The possibility that a word means a given thing as well as its contrary, or more simply a different thing, evidently is the origin of all of the rhetorical figures that include reference to the double meaning: irony, metaphor, litotes, oxymoron, preterition. One for all, irony manifestly says the opposite of what it actually means.

Abel reports that the philosopher Alexander Bain, in his Logic (1870), had postulated the double meaning of words as logically necessary, starting from the essential relativity of every kind of knowledge that makes reference to things by means of language-and language cannot but bear the marks of such relativity. The quotation from Bain's Logic reported by Freud, as suggested by Abel, states that "if everything that we can know is viewed as a transition from something else, every experience must have two sides; and either every name must have a double meaning, or else for every meaning there must be two names” (Freud, 1974: p. 189). If everything is also its own opposite, from the moment that every being becomes other than what it is, becoming is seen as the circular succession from one state to its opposite, and language cannot help but show this vision by which nothing can be thought of if not in relation to its opposite. Each term, therefore, must express the vocation to indicate the range of contraries. The isolation of the words to which an univocal meaning is attributed is the result of a lexicological drift towards semantic individualism that assumes the forgetting of the double meaning of the words or of the two terms referring to the same thing. I am unable to think of up without reference to down, courage without cowardice, love separated from hate.

Bain's contribution to the explanation of the semantic reversal phenomenon may be considered decisive, especially when one considers that each explanation must stem from an entirely evident and proven explicans. What is knowledge, according to Bain (1870)? Transition or change essentially. The cognitive action includes two things that coincide with the departure point and the arrival point of the transition. The same consideration can be applied to mental states. It is a known fact, Bain (1870) writes, that we know heat through the transition from cold, light when emerging from darkness, top in contrast to bottom. The object of knowledge is not absolute, but always relative to its opposite: we would be unable to know movement if we lacked the notion of immobility. We are able to focus our attention ona single property or quality only if we linger more on one member of the couple. For example, we can think more of heat than of cold, in which case heat will be the explicit term and cold the implicit. And since our transitions can occur in two directions (following the same example: from heat to cold and vice versa), our feelings will be different in the two cases. We have a livelier conscience of heat when we shift to a higher temperature, and of cold when we shift to a lower temperature. The principle of relativity enunciated by Bain envisages a sort of cognitive and conscious dualism which connotes the activity of the mind as a transition from one state to another, by which we are explicitly conscious of the arrival point and implicitly conscious of the starting point ${ }^{5}$. Bain (1870) applies the relativity principle to denomination, to definition and to preposition.

The ambivalence of psychic phenomena is a property of psychic activity that Freud (1974) knows well and that completes the phenomenological picture of the areas in which the objective of the activity of reflection and of denomination is the coincidentia oppositorum. Objectivity is totality, i.e. the synthesis of the opposites; thus, language must faithfully mirror the overall unity of contraries, consisting in terms that have opposite meanings. The phenomenon of opposite meaning runs so deep and is so pervasive that many examples of it are found in every language. Abel reports the Latin clamare (to cry) and clam (softly, secretly); siccus (dry) and succus (juice); the German kleben (to stick) and the English to cleave; the English without, that literally means "with-without". The word with itself, originally meant without as well as with, as can be recognised from withdraw and withhold. The same transformation can be seen in the German wider (against) and wieder (together with) (Freud, 1974: pp. 189-190).

Abel calls attention to the phonetic reversal phenomenon that in ancient Egyptian seems to be parallel to semantic reversal. The examples of phonetic reversal, or metathesis, seen in European languages are too frequent to be chance occurrences, says Freud (1974). Just to mention a few, see hurry and Ruhe (German for rest). In other cases, phonetic reversal is not accompanied by semantic reversal: capere (Latin for to take) and packen (German for to seize); ren (Latin for kidney) and Niere (German for kidney) (Freud, 1974: p. 190).

Karl Abel's theory was criticised by illustrious glottologists and linguists, as mentioned by Giulio C. Lepschy in an essay that relates the history of the review of the famous book by the linguist quoted by Freud (Lepschy in Romaniello, 2004: p. 172). Benveniste (1976) produced the most radical critique of Abel's theory, denouncing the arbitrariness of his etymologies (used by Freud as argument supporting his own theory of the unconscious).

\footnotetext{
5“The state we have passed to is our explicit consciousness, the state we have passed from is our implicit consciousness” (Bain, 1870: p. 3).
} 
Benveniste (1976) also points a finger at the impossibility of finding primitive or stone-age languages in which terms with opposite meaning can be found, finally underlining that the unconscious cannot be assimilated with a natural language (Romaniello, 2004: p. 172). According to Benveniste (1976), the symbolism of the unconscious has no linguistic nature: Abel's theory, from which Freud (1974) insists in extracting solid arguments in support of his own psychoanalytical theory, especially as regards the interpretation of dreams, is groundless. Naturally, Benveniste (1976) and other linguists-all strongly if not uncompromisingly critical of Abel's theory-do not doubt Freud's theory, but merely point out the unsustainability of Abel's linguistic theory. Romaniello (2004) strongly backs Benveniste's demolishing attack against the thesis of the author of Über den Gegensinn der Urworte: the enantiosemia phenomenon does not exist in any language, because no linguistic term is ever used isochronically in two opposite meanings. The passage from the Latin "feriae" (that indicated the days dedicated to religious holidays, therefore not working days) to the Italian "feriale" (that stands for "working day"), for example, has nothing to do with enantiosemia. The semantic reversal in time of ferialis from "holiday" to "work day" finds its explanation in historical and extra-linguistic circumstances, namely the religious revolution and the triumph of Christianity ${ }^{6}$. Lepschy, who was much less uncompromising than Benveniste (1976), is willing to admit the existence of the enantiosemiaphenomenon as one of the mechanisms that are behind every linguistic system and sets as an irrefutable example the Latin word fortuna. The actual meaning of fortuna, however, it being a derivative of fors (chance, fortuitous event), is neither good fortune nor bad fortune, because these meanings are achieved only when fortuna is accompanied by secunda, prospera, florentissima, or adversa, iniqua (Romaniello, 2004: p. 185). In short, the semantic bivalence, by which the same word has two opposite meanings in the same language, does not exist, since no word can mean two opposite things at the same time. If a speaker used terms having a double meaning, he would confuse his listeners and communication would become impossible. At this point, it would be better to distinguish between two orders of language-analogic and numericor verbal—assigning the enantiosemiato the analogic language.

\section{The Enantiosemia of Sacrifice}

The analogical language differs in many ways from the verbal or numerical language. Analogically it is impossible to lie, to use the logical linkers or the conjunctions and prepositions of verbal discourse, and there is no equivalent for "non". Something akin to this occurs in primitive ideographic writing, where the units of meaning are images. The Palo Alto scholars who wrote Pragmatics of human communication underline the intrinsic ambiguity of analogical messages: "There are tears of pain and tears of joy; the tightening of fists can be interpreted as a sign of aggressiveness or of constriction; a smile may express comprehension or contempt; reservedness may be a sign of indifference or of tactfulness” (Watzlawick, 1971: p. 58). The authors of Pragmatics of human communication add that it is impossible not to wonder whether all analogical messages possess the same ambiguity, and not remember the Freudian Gegensinn der Urworte. Analogical communication would therefore lack indicators and qualifiers capable of specifying which of the two meanings is the correct one. The opposite meaning of primal words, recalled by the Palo Alto scholars, may be explained as a phenomenon of survival or transposition from the analogical to the numerical or verbal of a feature typical of analogical language. Verbal

\footnotetext{
${ }^{6}$ The semantic change offeriae, that has nothing to do with enantiosemia, stems from the systematic "damnatio memoriae" of pagan cult and, in particular, of that which dominated in the last two centuries (I-III centuries A.D.) of the god Mitra, the "Sol invictus", whose festivity, that coincided with the winter solstice, was replaced with the Christmas of Christ, the new Saving Sun, set on 25 December precisely for the "damnatio memoriae" that also imposed the reconsecration of the days dedicated to pagan deities, all of which were consecrated to the sole new God/Lord of men. Consequently, every day received the qualification of "feria", a singular form of "feriae", rarely used and revived for the purpose, that meant "day dedicated to God" = "holy day" (Romaniello, 2004: p. 182). Thus the new naming of the days of the week starting from "Domenica” (Sunday), the day of the Lord par excellence: prima feria, feria secunda, feria tertia, etc.

${ }^{7}$ The fallacy of amphiboly introduces a syntactical type of ambiguity, since it depends on the way the words are arranged. An amphibolic assertion allows for more than one interpretation, one of which is true. An easy example is the genitive, which can be subjective or objective (the fear of enemies). Ennius in the Annales reports the response that the oracle gave Pyrrhus: Aio te, Aeacida, Romanos vincere posse, where the objective proposition has two opposite meanings: Pyrrhus can overthrow the Romans, and vice versa. Another example is found in Herodotus, Histories I 86, 5-6; I 87: "Croesus the king of Lidia moves war against the Persian sovereign Cyrus, after consulting the oracle of Delphi. The god had foretold that, should he attack Cyrus, a great realm would have collapsed, but Croesus didn't even suspect that the realm destined to fall was his own. The defeated king, condemned to death and placed on the pyre, also remembers the admonishment not to consider himself fortunate before the end of his life, given him some time before by Solon. His mentioning the name of the Athenian wise man intrigues Cyrus. Impressed by the story the king tells, the conqueror renounces his cruel triumph and welcomes Croesus as a friend". Any event confirms the response and makes it sound veracious: the priests who had emitted it have nothing to be blamed for. The priests could have been blamed for being wrong only if the clash between the two armies had finished without winners or losers. In that case, neither of the two realms would have collapsed.
} 
language, however, by its own nature seems incapable of admitting any form of enantiosemia: every word has a single meaning in the same occurrence. Misinterpretation is possible, but it implies a discrepancy between the meaning intended by the emitter and that intended by the recipient. Perhaps amphiboly ${ }^{7}$-not surprisingly classified as a fallacy from the point of view of verbal language- is the construction most similar to enantiosemia. In the end, though, the ambiguity ante factum dissolves when, post factum, it proves obvious that only one interpretation was the correct one. As in analogical language, the amphibology construction lacks the indicators that help identify a univocal meaning. Human beings must however combine the two languages and translate from one into the other. There is no symmetry between the two: one cannot describe the numerical language by using the analogical one, but one can speak of the analogical one using the numerical module. Just think of the difference between courting and marriage contract (Watzlawick, 1971: p. 59). The first is based on the analogical language, the second on the numerical one. Two people who are engaged decide to marry: after the marriage they can continue to wonder whether they are together because they want to or because they have to, spontaneously or perforce. The old Italian saying "wedlock is the death of love" is nothing but the dramatization of the problem that arises when the analogical dimension of the sentimental relationship is superseded by a kind of rewriting or translation from analogical to numerical.

In this context, one can turn to the fundamental paradigm of this semantic opposition represented by the notions of sacred and of sacrifice. Sacer is an example of a word with a double meaning: sacred and sacrilege, saintly and heinous. Sacrificium is the action of making sacred (sacrum facere). The victim of the sacrifice is made sacred by means of its own killing. Originally, that which Girard calls a crisis of undifferentiation, featuring every one against every one, culminates in the selection of an individual responsible for the dark evil that tears asunder the chaos-striken community: this results in everyone against one, when the persecutors and the victim itself become persuaded that only one is responsible for the ruin that has hit all of them. After the lynching, the symbolical valence of the victim transforms into its opposite: from almost invincible evil power to absolute beneficial power, since the victim's expulsion has allowed the community to return to the status of peace that reigned prior to the crisis (Girard, 1980, 1987). The victim itself is evil and beneficial, destructive and constructive. The mythical god, arisen from the sacralisation of the expelled victim, allows for or wants even tragic events that remove all hope, thus revealing his origin from the victim, his ambivalent status of victim guilty of the spreading conflicts and simultaneously of saviour of the same community that lynched it. The mythical god is beneficial and evil, loving and vindictive. Archaic man relates to the divine based on this fundamental ambivalence, by which when the God is explicitly thought of as a beneficial power, its nature as evil power remains implicit and, vice versa, when on the occasion of tragic calamities or devastating events the same divinity is thought of explicitly as an evil genius and the cause of the catastrophe, its saving action remains implicit. The re-awakening of the divinity's saving power is brought about using sacrificial rites the purpose of which is to renew the beneficial power, the healing effectiveness of the expelled and sacralised victim (Tugnoli, 2001) ${ }^{8}$. The relationship between the expelled victim and the divinity, resulting from the victim's sacralisation, remains unconscious. Many myths illustrate the lynching scene metaphorically, starting from Oedipus.

Giovanni Semerano (1994), in radical contrast with official linguistics, proposes the refounding of the lexicon of European languages on a Semitic base (Semerano, 1994). As regards macto/mactare (to put down, to sacrifice), Semerano deems simplistic the ancient etymology that wants them derived from "magis aucto", indicating as totally persuasive the derivation from the Akkadian maqātu (to be put down, to attack, to put down). The root of the ancient Akkadian MQT (to kill) is the basis for maqtu (put down, fallen). The value of "sacrifice", Semerano explains, comes from the matching with the base corresponding to the Akkadian maqqû (libation, sacrifice) and maqqītu (sacrificial offering, libation). According to Semerano, traditional etymology has failed to take into account the fact that victima has the same etymological basis of macto and is equivalent to the Akkadian wiqittum (miqittum: putting down). Semerano rejects the connection, that traditional etymology takes for granted, between mactare and mactus, indicating two different etymological bases: the basis of mactus, macte (satisfied, abundant) would seem to correspond to the phenomenon of an original occlusive laryngeal (see *mag-) stemming from the Sumerian mah, Akkadian ma'du (abundant, large, generous) and quite common in the Semitic languages: Ugaritic, Arabic, Hebrew. Cf.: Akkadian ma'ādu (to be abundant, to multiply, to abound, to gain, to obtain); ma'dis (much, greatly).

${ }^{8}$ Cf. C. Tugnoli: http://www.academia.edu/2566746/IL_CIRCOLO_NON_VIZIOSO_DI_GIRARD; http://mondodomani.org/dialegesthai/ct06.htm; http://mondodomani.org/dialegesthai/ct23.htm where I discuss these aspects of the mimetic theory. 
Instead macto would have another base, corresponding to the Akkadian maqtu (put down), from mqātu (to fall, to be put down and to put down), crossed with maqqû (libation), that closely follow the base corresponding to the Semitic mhd, Akkadian mahasu (to kill, to put down) (Semerano, 1994: I, pp. 463-464). Victima (sacrifice, victim, sacrificial offering) has the same etymological base as macto, Akkadian miqtum (read: wiqtum, putting down, fall) from maqātu (to be put down, to fall) (Semerano, 1994: II, p. 612). At the etymological level, Semerano's hypothesis justifies the connection between sacrifice and victim, by which practically there is no sacrifice without a victim. The victim can be he who sacrifices or he who is sacrificed.

\section{The Victimary Ratio of Mactare}

The interpretation Emanuele Severino (2013) suggests for the etymology of mactare allows focusing on the difference between his concept of the divine and René Girard's mimetic-sacrificial theory. Severino observes that mactare in Latin means “to kill” (cf. "mattanza” in Italian and matar in Spanish, which means "to kill”) (Severino, 2013: p. 302). Mactus is a Latin word, however, that means enlarged, reinforced, elevated, glorified, and that together with magnus shares the Indo-European root magh, also found in the Greek word mechané. Mactus could be the crasis of magis auctus, which would therefore mean "made even larger and richer". Hence mactare means to elevate, to enlarge, to glorify, but also to honour, to placate, which is referred to a god recipient of the sacrifice or invocation. Severino writes that "Mactare shifts the focus from the god to which one is sacrificing (mactare deum extis, "to reinforce" the god with the viscera of the sacrificial victim) to the instrument of the sacrifice, namely the victim, and thus also means "to kill”: "mactare victimam appears next to mactare deum" (Severino, 2013: pp. 302-303).

Severino (2013) identifies the in-depth reason of the etymological semantics of mactare in the archaic man's need to remedy the anguish he feels when faces with the changes in himself and in the things of the world, all subject to birth and death. The anguish caused by the becoming other of everything is overcome by the alliance with the power of the god. If the power of the god is the only hope of salvation, man must protect and increase this power. In the times when myth reigned, man reinforced divine power by sacrificing himself and what he possessed. Later on God was reinforced through philosophy, which celebrated Him as the invincible, unalterable, eternal power that is capable of safeguarding everything. In Severino's theoretics, the concept of an invisible and omnipotent God, the cause of Himself and of the world, takes on the role of permanent and incontrovertible negation of the destruction to which everything is apparently destined. The metaphysical reflection on the eternal and unalterable power therefore has the same function as sacrifice, namely that of setting up an effective remedy against the becoming, which causes anguish because it opens a void before the eyes of man.

Severino's reconstruction does not take into account the origin of the god. Does the immutable come into play only as the negation of the becoming? If everything becomes and transforms into its other, what could be the matrix of divine power, opposed to becoming through its being eternal and unalterable? With Girard, we can explain the expression mactare victimam as perfectly correspondent to the meaning of the original lynching of a human victim burdened of every evil afflicting the community. The victim that is expelled as a result of the unanimous convergence of the hatred of the persecutors, in the wake of the transformation from "every one against every one" to "everyone against one", that identifies in it the cause of the spreading crisis, becomes by virtue of its own suppression the cause of well-being, of peace and of order of the same community. The victim therefore is killed and then sacralised. Any victim of a murder is subject to the same fate: the victim is enlarged, magnified, glorified simply because he or she has been murdered. The same happens, more in general, as a consequence of someone's death due to natural causes, as if those who knew the deceased in life felt responsible for his or her death, although they had no part in bringing about the tragic event.

In conclusion, the scapegoat theory perfectly explains the simultaneous presence, in mactare victimam, of two meanings: to kill on the one hand and to elevate, to glorify on the other hand. In the case of the original lynching, which in myth is usually hidden, the victim, who at first is killed because it is deemed the cause of all evil, is then deified as the cause of all good for those who killed it. Hence the need to reinforce and periodically renovate via human or animal sacrifices, the saving power of the divinity created through the murder of the first victim. This explains why to kill and to glorify coexist in mactare, that is both mactare victimam and mactare deum, since the verb means to kill when it is referred to a victim and to glorify when it is referred to a god. Indeed, the deification of the victim is the consequence of the victim's murder. Unless one reconstructs the genesis of the archaic sacred in the light of victimary anthropology, one would be tempted to indicate the verb mactare as an example of enantiosemia. 
Severino and Girard only have the anthropological character of the genesis they propose for the god in common (in Severino, the unchangeable as containment and negation of the becoming, so as to contrast the horror of the void and to win over the contradiction of the becoming; in Girard, the sacralisation of the victim killed and transformed from evil omnipotence into beneficial omnipotence). The negation of nothingness and the victory against the horror felt when facing the becoming can be achieved by means of the killing of a victim. Could this be the genesis of that archaic god that, for Severino, intervenes in the post-mythical phase in the shape of the unchangeable within the strictly philosophical reflection?

\section{References}

Bain, A. (1870). Logic. London: Longmans-Green-Reader-Dyer.

Basile, G. (1999). “Le parole di significato opposto prima di Carl Abel” in Annali dell’Università degli Studi di Napoli “L’Orientale”. Rivista del Dipartimento del mondo classico. Sezione Linguistica, 1997, 29-62.

Benveniste, E. (1976). Le vocabulaire des institutions indoeuropéennes. (1969) Italian Title: Il vocabolario delle istituzioni indoeuropee, edited by M. Liborio, Volume 2, Turin: Einaudi.

Calonghi, C. (1967). Dizionario latino-italiano. The Entirely Abridged and Updated 3rd Edition of the Georges-Calonghi Dictionary (1950), Turin: Rosenberg \& Sellier.

Conte, G. B., Pianezzola, E., \& Ranucci, G. (2000). Dizionario della lingua latina. Milan: Le Monnier-Mondadori.,

Devoto, G. (1968). (Le Monnier, 1966) Avviamento alla etimologia italiana. Dizionario etimologico (2nd ed.).

Ernout, A., \& Meillet, A. (1967). Dictionnaire étymologique de la langue latine. Histoire des mots (Quatrième édition). Paris: Librairie C. Klincksieck.

Freud, S. (1974). Significato opposto delle parole primordiali. In S. Freud (Ed.), Opere, Vol. VI, $1909-1912$ Casi clinici e altri scritti, Turin: Boringhieri.

Gesner, J. M. (1749). Novus Linguae Latinae Thesaurus. tom. III, coll. 168.

Girard, R. (1980). La violence et le sacré. (1972) Italian Title: La violenza e il sacro, by O. Fatica and E. Czerkl. Milan: Adelphi.

Girard, R. (1983). Des choses cachées depuis la fondation du monde, 1978, Italian title Delle cose nascoste sin dalla fondazione del mondo, by R. Damiani. Milan: Adelphi.

Girard, R. (1987). Le bouc émissaire. Italian Title: Il capro espiatorio. By Ch. Leverd, \& F. Bovoli. Milan: Adelphi.

Peduto, M. D. (1993). Le parole con significato opposto. AISN, 15, 65-88.

Romaniello, G. (2004). Pensiero e linguaggio. Grammatica universale, Sovera editore, Rome.

Semerano, G. (1994). Le origini della cultura europea. 2 Volumes, 4 Books. Florence: Olschki.

Severino, E. (2013). La potenza dell'errare. Sulla storia dell'Occidente. Milan: Rizzoli.

Thesaurus Linguae Latinae (1966). Editus iussu et auctoritate consilii ab academiis societatibusque diversarum nationum electi. volumen VIII, M, Lipsiae in aedibus B. G. Teubner.

Tugnoli, C. (2001). Girard. Dal mito ai vangeli. Edizioni Messaggero, Padua.

Walde, A., \& Hofmann, J. B. (1982). Lateinisches Etymologisches Wörterbuch. Zweiter Band, M-Z, Carl Winter Universitätsverlag, Heidelberg.

Watzlawick, P., Beavin, J. H., \& Jackson, D. D. (1971). Pragmatics of Human Communication. A Study of Interactional Patterns, Pathologies and Paradoxes. (1967) Italian Title: Pragmatica della comunicazione umana. Studio dei modelli interattivi, delle patologie e dei paradossi. di M. Ferretti, Astrolabio, Rome. 